\title{
Pro-QUAlity ACTIVITIES IN THE PUBLIC FINANCE SECTOR UNIT. THE IMPORTANCE AND ROLE OF THE INTEGRATED MANAGEMENT SYSTEM IN THE OPINION OF PEOPLE IN MANAGERIAL POSITIONS AND OTHER EMPLOYEES
}

\author{
DZIAŁANIA PROJAKOŚCIOWE W JEDNOSTCE \\ SEKTORA FINANSÓW PUBLICZNYCH - ZNACZENIE \\ I ROLA ZINTEGROWANEGO SYSTEMU ZARZĄDZANIA \\ W OPINII OSÓB BĘDĄCYCH NA STANOWISKACH \\ KIEROWNICZYCH I POZOSTAŁYCH PRACOWNIKÓW
}

\begin{abstract}
Quality management is the task of all managers to perform management functions in relation to the quality of the managed system and the quality of its components. This is an approach in which quality is the most important issue in management decisions. In times of increasing customer demand and changing management standards in public finance, bolder models and methods of improving the quality of public services are becoming increasingly bold, taking into account the expectations and needs of today's public. The aim of this article is to present the state of quality policy management in a public finance sector unit, including the assessment of the degree of implementation of the integrated management system (IMS) in the organization and its impact on the performance of the tasks of the office. The goal was achieved through literature studies, source documentation analysis, and empirical research examining the functioning of the IMS at the office, including access to resources such as knowledge or information. The areas of competence and involvement of those in managerial positions and other employees were also assessed, particularly important in the building and improvement of IMS. Conclusions from the research indicate
\end{abstract}


that it is crucial to understand common problems of quality, to define it and to create a friendly environment through a pro-quality organizational culture that will allow building a pro-quality orientation.

\section{STRESZCZENIE}

Zarządzanie jakością to zadanie wszystkich menedżerów polegające na wykonywaniu funkcji zarządzania w stosunku do jakości systemu zarządzanego i jakości jego składników. Jest to podejście, w którym jakość jest najważniejszą kwestią w decyzjach kierowniczych. W dobie zwiększających się wymagań klientów i zmiany standardów zarządzania w jednostkach sektora finansów publicznych coraz odważniej wykorzystywane są modele i metody doskonalenia jakości usług publicznych, które biorą pod uwagę oczekiwania i potrzeby współczesnego odbiorcy. Celem artykułu jest prezentacja stanu zarządzania polityką jakości w jednostce sektora finansów publicznych z uwzględnieniem oceny stopnia wdrożenia zintegrowanego systemu zarządzania (ZSZ) w organizacji i jego wpływu na realizację zadań urzędu. Cel osiągnięto za pomocą studiów literaturowych, analizy dokumentacji źródłowych oraz badań empirycznych, w których przeanalizowane zostało środowisko funkcjonowania ZSZ w urzędzie, $w$ tym dostęp do zasobów takich jak wiedza czy informacje. Ocenione zostały ponadto obszary kompetencji i zaangażowania osób będących na stanowiskach kierowniczych i pozostałych pracowników, jako szczególnie istotne w budowaniu i doskonaleniu ZSZ. Wnioski z badań wskazują, że kluczowe jest wspólne rozumienie problemów jakości, wspólne definiowanie i stworzenie środowiska jej przyjaznego - przez projakościową kulturę organizacyjną, które pozwolą na budowanie projakościowej orientacji pracy.

KEYWORDS: integrated management system, quality management in public finance sector unit, pro-quality orientation

SŁOWA KLUCZE: $z$ integrowany system zarządzania, zarządzanie jakościa w jednostce sektora finansów publicznych, działania projakościowe

\section{WPROWADZENIE}

Zarządzanie jakością to zadanie wszystkich menedżerów polegające na wykonywaniu funkcji zarządzania w stosunku do jakości systemu zarządzanego i jakości jego składników. Jest to podejście, w którym jakość jest najważniejszą kwestią w decyzjach kierowniczych. Działanie to decyduje o polityce jakości, celach i odpowiedzialności oraz realizacji w ramach systemu jakości (Opolski, Dykowska, Możdżonek, 2009, s. 139-140). 
Przesłaniem stworzenia, a następnie zastosowania w praktyce rozwiązań w zakresie nowoczesnych metod zarządzania w administracji publicznej wiążą się z koncepcjami tzw. nowego zarządzania publicznego (NPM - New Public Management) rozpowszechnionymi szczególnie w krajach anglosaskich od około 40 lat. Podstawowe założenia NPM były skierowane na zwiększanie efektywności jednostek sektora finansów publicznych m.in. przez nacisk na zarządzanie finansami (efektywność), wyznaczanie celów i monitorowanie wyników oraz wyznaczanie standardów usług.

W Polsce powszechną debatę na temat metod i standardów działania administracji publicznej zapoczątkowała reforma samorządowa z 1999 roku. Z każdym rokiem na przestrzeni ostatnich 30 lat jednostki sektora finansów publicznych (urzędy centralne, administracja samorządowa, szpitale, szkoły itp.) coraz odważniej wykorzystywała modele i metody doskonalenia jakości usług publicznych, biorąc pod uwagę oczekiwania i potrzeby współczesnego odbiorcy. Obecnie wiele urzędów posiada certyfikat potwierdzający funkcjonowanie systemu zarządzania zgodnego z wymaganiami norm ISO 9001, która określa podstawowe wymogi zarządzania przez jakość. Często działania te nie były wynikiem nacisków, lecz samodzielną decyzją o podjęciu zmian adaptujących wzorce z innych państw (Kozera, 2009, s. 75). Według St. Tkaczyka (2004, s. 174) doskonalenie jakości funkcji zarządczych organizacji zarządzanej na podstawie kryterium jakości powinno być odzwierciedlone we wzroście efektywności jej zarządzania.

Efektywne zarządzanie administracją publiczną wymaga określenia strategii celów działania urzędu, ukierunkowanego na sprawny system organizacji pracy i kształtowanie pozytywnego wizerunku (Szejniuk, 2014, s. 245-265). Pomocnym instrumentem w tworzeniu i wdrażaniu nowego systemu administracji publicznej stają się nowe normy określające wymagania i zasady zarządzania jakością w organizacji. Według St. Tkaczyka (2006, s. 35-39) podstawowym celem zarządzania jakością w organizacji jest takie udoskonalenie systemów i procesów, które pozwoli na ustawiczną poprawę jakości.

Jakość usług w administracji publicznej zależy od wielu czynników, m.in. (Bugdol, 2008, s. 31): społecznych (np. kompetencje, komunikacja, otwartość, przywództwo), ekonomicznych (możliwość doskonalenia jakości, dofinansowania, subsydia, koszty społeczne i ekonomiczne), organizacyj- 
noprawne (obowiązujące przepisy prawa, powiązania między procesami), techniczno-środowiskowe (np. otoczenie, infrastruktura, rozwój e-usług). Klient odgrywa bardzo ważną rolę w zarządzaniu jakością w administracji publicznej, ponieważ ocenia poziom jakości świadczonych usług (Frąś, 2008, s. 42-43). W urzędach funkcjonuje wiele określeń klienta, do najczęściej używanych można zaliczyć: strona, petent, interesant. Stroną według Kodeksu postępowania administracyjnego jest każdy, czyjego interesu prawnego lub obowiązku dotyczy postępowanie, albo kto żąda czynności organu ze względu na swój interes prawny lub obowiązek. Stronami mogą być osoby fizyczne i osoby prawne, a gdy chodzi o państwowe i samorządowe jednostki organizacyjne i organizacje społeczne - również jednostki nieposiadające osobowości prawnej.

\section{ZINTEGROWANY SYSTEM ZARZĄDZANIA (ZSZ) W TEORII}

Zintegrowany system zarządzania (ZSZ) to połączenie procesów, procedur i praktyk działania stosowanych w organizacji w celu wdrożenia jej polityki, które może być bardziej skuteczne w osiąganiu celów wynikających z polityki niż podejście przez oddzielne systemy. Zintegrowany system zarządzania jest polecanym i najkorzystniejszym rozwiązaniem dla organizacji, która ma zamiar wprowadzić kilka różnych systemów zarządzania. W zależności od specyfiki branży i planów, jakie organizacja chce zrealizować w danym czasie, wdraża ona zintegrowany system zarządzania składający się z różnych podsystemów. Zazwyczaj podstawą większości takich projektów jest system zarządzania jakością zgodny z wymaganiami normy ISO 9001. Należy jednak podkreślić, że wszystkie systemy wchodzące w skład ZSZ powinny być traktowane równorzędnie, nie należy traktować w sposób priorytetowy jednego z systemów tworzących ZSZ czy pozostałych systemów jako podsystemy. Zasada równoważności systemów jest fundamentem w systemie zintegrowanym (Roszak, 2012, s. 181). Według E. Skrzypek (2014, s. 58) warunkami powodzenia efektywnego i skutecznego zintegrowanego systemu zarządzania są:

- motywacja pracowników, kreatywność zbiorowa i indywidualna,

- tworzenie szansy na sukces rynkowy,

- zaangażowanie kierownictwa, 
- kompleksowość podejścia do zintegrowanych systemów zarządzania,

- zaangażowanie kierownictwa, właściwy stosunek do wiedzy,

- poszukiwanie sposobów stałego doskonalenia zarządzania,

- podmiotowe traktowanie pracowników, potraktowanie zmiany jako szansy, a nie zagrożenia,

- efektywne wykorzystanie czasu, wytrwałość, cierpliwość, konsekwencja, wymagania.

W świetle powyższego efektywnie działający zintegrowany system zarządzania w organizacji powinien być wrażliwy na zmiany. Ponadto w znacznej części uzależniony od przekonań dotyczących słuszności tych zmian wśród uczestników biorących udział we wdrażaniu rozwiązań i stosowaniu tego systemu.

\section{Metody BADAwCZE}

Celem głównym postawionym przed realizacją badań jest zdiagnozowanie stanu zarządzania polityką jakości w jednostce sektora finansów publicznych z uwzględnieniem oceny stopnia wdrożenia zintegrowanego systemu zarządzania (ZSZ) w organizacji i jego wpływu na realizację zadań urzędu z perspektywy osób będących na stanowiskach kierowniczych i pozostałych pracowników. Powyższy cel osiągnięto, skupiając się na uszczegółowieniu czynników, jakie kształtują systemy zarządzania jakością, ale również czynników jakości z perspektywy działania urzędu administracji publicznej ocenianych przez codzienny wymiar pracy urzędu. Określono następujące cele szczegółowe:

- Identyfikacja stanu wiedzy i kompetencji pracowników (w tym osób na stanowiskach kierowniczych) urzędu na temat funkcjonowania zintegrowanego systemu zarządzania w urzędzie.

- Identyfikacja wpływu wdrażania zintegrowanego systemu zarządzania na funkcjonowanie urzędu.

- Identyfikacja zjawisk, wpływających pozytywnie oraz negatywnie na funkcjonowanie zintegrowanego systemu zarządzania w urzędzie.

- Określenie rekomendacji dla kierownictwa urzędu/ów, w kontekście usprawnień i doskonalenia systemu zarządzania. 
Kierunek osiągania celów szczegółowych wytyczyły hipotezy w formie pytań badawczych, które skupione zostały głównie w obszarze jakości zarządzania urzędem, jako podstawowego czynnika, decydującego o jakości pracy urzędu w ogóle. A mianowicie:

H1: Czy zaangażowanie i kompetencje pracowników (w tym osób na stanowiskach kierowniczych) urzędu we wdrażania zintegrowanego systemu zarządzania są na dość wysokim poziomie?

H2: Czy funkcjonowanie zintegrowanego systemu zarządzania sprzyja poprawie funkcjonowania urzędu?

H3: Czy zaangażowanie kierownictwa urzędu w funkcjonowanie zintegrowanego systemu zarządzania jest ważnym elementem doskonalenia jakości zarządzania?

Postawione hipotezy badawcze w formie pytań korespondują bezpośrednio z celami badania, które koncentrują się wokół czynników wpływających na zarządzanie jakością w organizacji.

Dla osiągnięcia celów badania wykorzystano różne metody i techniki badawcze, czyli zastosowano tzw. triangulację metodologiczną w odniesieniu do źródeł danych i metod badawczych. Wykorzystano różne źródła informacji i przyjęto dwa etapy badań.

A mianowicie:

- Poddano analizie wtórnej istniejące informacje i dokumenty. W ramach tego etapu badania dokonano analizy zintegrowanego systemu zarządzania w urzędzie, identyfikując przyjęte przez urząd metody i narzędzia zarządzania jakością.

- Pierwotne informacje pozyskano przez badanie CAWI (z ang. Computer Assisted Website Interview), czyli metodę badania kwestionariuszowego prowadzonego za pośrednictwem internetu, a dokładnie bazy Lotus Notes. Kwestionariusz badawczy składał się z pytań obejmujących w sumie cztery bloki tematyczne:

- ogólny obraz kompetencji pracowników w zakresie ZSZ;

- ocena korzyści dla organizacji z wdrażania ZSZ;

- ocena funkcjonowania ZSZ;

- ocena uwarunkowań funkcjonowania ZSZ. 
W przyjętym podziale tematycznym ankiety przeanalizowane zostało środowisko funkcjonowania ZSZ w urzędzie, w tym dostęp do zasobów takich jak wiedza czy informacje. Ocenione zostały ponadto obszary kompetencji i zaangażowania pracowników, jako szczególnie istotne w budowaniu i doskonaleniu ZSZ. Ostatni oceniony obszar umożliwił analizę postrzegania ZSZ w urzędzie przez uczestników badania. Podział ten nie został odzwierciedlony w ankiecie.

Takie podejście zapewniło skupienie uczestników badania na poszczególnych pytaniach i ich treści, bez potrzeby sugerowania, jakie obszary są przez nich oceniane.

Generalnie celem badań ilościowych było poznanie opinii pracowników i ich świadomości w zakresie zintegrowanego systemu zarządzania w urzędzie oraz poziomu zaangażowania kierownictwa urzędu we wdrażanie systemowych rozwiązań na rzecz jakości pracy urzędu. Badanie ilościowe umożliwiło oszacowanie liczbowe badanych zjawisk oraz zebranie materiału informacyjnego pochodzącego z najbardziej miarodajnego źródła - od pracowników urzędu odpowiedzialnych za kreowanie i stosowanie polityki jakości w organizacji. Taka koncepcja badań w ramach pierwszego oraz drugiego etapu pozwoliła na osiągnięcie celu badania. Badanie jakościowe przeprowadzono w połowie 2014 roku, w którym wzięło udział 175 pracowników urzędu, co stanowi 17,09\% ankietowanych, tj.: 1024 ogółu pracowników urzędu osiadających dostęp do komputera, według stanu zatrudnienia na dzień 31 lipca 2014 roku. Wśród osób, które wzięły udział w badaniu, $21,71 \%$ stanowiły osoby zajmujące stanowiska kierownicze (dyrektorzy, zastępcy dyrektorów i naczelnicy), natomiast 78,29\% stanowili pozostali pracownicy urzędu. Wśród osób, które wzięły udział w badaniu, największą grupę stanowili pracownicy zatrudnieni w urzędzie powyżej 10 lat (34,29\%), następnie pracownicy o stażu pracy do 10 lat $(33,71 \%)$, do 5 lat $(26,86 \%)$.

Najmniejszą zaś grupę stanowili pracownicy o stażu pracy w urzędzie wynoszącym poniżej 1 roku (5,14\%). Wśród ankietowanych 13,71\% stanowiły osoby pełniące funkcję koordynatora bądź zastępcy koordynatora departamentalnego zintegrowanego systemu zarządzania, natomiast 86,29\% to pozostali pracownicy. 


\section{PrezentaCJA WYNIKóW BADAŃ}

\section{Zintegrowany system zarządzania - studium przypadku}

Niniejszy artykuł poniżej przedstawia podejmowane działania na rzecz zarządzania jakością w jednostce sektora finansów publicznych na przykładzie jednostki sektora finansów publicznych - Ministerstwa Gospodarki. Działania na rzecz zarządzania jakością w Ministerstwie Gospodarki (MG) zostały zapoczątkowane w październiku 2006 roku przez przystąpienie przez Ministerstwo Gospodarki do realizacji pilotażowego projektu: „Wdrożenie metody CAF w wybranych ministerstwach i urzędach centralnych”. W 2007 roku kierownictwo MG podjęło decyzję o wdrożeniu Systemu Zarządzania Jakością wraz z Systemem Przeciwdziałania Zagrożeniom Korupcyjnym (efekt zaleceń z I samooceny CAF przeprowadzonej w 2007 roku). Od 2008 roku wprowadzono System Zarządzania Jakością, który wprowadził podejście projektowe i procesowe, bazując na standardach normy ISO 9001. Od 2012 roku decyzją Kierownictwa MG wdrożono Zintegrowany System Zarządzania. Kierownictwo urzędu w rozumieniu normy ISO 9001. Zintegrowany System Zarządzania na mocy wewnętrznych aktów prawnych - zarządzeń Dyrektora Generalnego - tworzyły:

- System Zarządzania Jakością (SZJ) - zgodny z wymogami normy ISO 9001;

- System Przeciwdziałania Zagrożeniom Korupcyjnym (SPZK) - stanowiący rozwinięcie wymagań normy ISO 9001 o dodatkowe wymagania związane z procesami antykorupcyjnymi;

- System Zarządzania Bezpieczeństwem Informacji (SZBI) - zgodny z wymaganiami normy ISO/IEC 27001.

System Zarządzania Jakością (SZJ) ustanowiony został w celu rzetelnej realizacji zadań związanych z realizacją misji i Planu Zarządzania Strategicznego, w którym zostały określone priorytety strategiczne i operacyjne. System Przeciwdziałania Zagrożeniom Korupcyjnym (SPZK) uwzględniający politykę państwa w zakresie przeciwdziałania korupcji został ustanowiony w celu rzetelnej realizacji zadań oraz zwiększenia zaufania społecznego do urzędu. Natomiast System Zarządzania Bezpieczeństwem Informacji (SZBI) ustanowiony został w celu zapewnienia wysokiego poziomu bezpieczeństwa, 
tj. zachowania poufności, integralności oraz dostępności informacji przetwarzanych w urzędzie. Generalnie Zintegrowany System Zarządzania wprowadzono w Ministerstwie Gospodarki w celu zapewnienia, jak również ciągłego doskonalenia jakości, sprawnej obsługi obywateli i przedsiębiorców, wysokiego poziomu bezpieczeństwa przetwarzanych informacji oraz rozwiązań zarządczych i organizacyjnych w urzędzie. Zintegrowany System Zarządzania obejmował realizację wszystkich usług publicznych pozostających w gestii ministra, dla których powołano urząd, jak również działania związane z zapewnieniem funkcjonowania organizacji jako urzędu administracji centralnej. Zintegrowany System Zarządzania został wdrożony i utrzymywany we wszystkich komórkach organizacyjnych i we wszystkich siedzibach urzędu.

W zakresie ZSZ opracowano dokumentację systemową, w szczególności: Politykę ZSZ, Księgę ZSZ, Deklarację stosowania, karty procesów, procedury systemowe i operacyjne oraz formularze wewnętrzne funkcjonujące niezależnie - poddawane stosownej aktualizacji.

W kontekście nadzoru nad ZSZ członkom Kierownictwa został określony zakres odpowiedzialności i uprawnień w zakresie ZSZ i zawarty w regulacjach wewnętrznych urzędu, w sprawie podziału pracy w Kierownictwie Ministerstwa Gospodarki i regulaminie organizacyjnym. Natomiast podstawowymi zadaniami komórek organizacyjnych są podnoszenie jakości i efektywności działania oraz poziomu bezpieczeństwa informacji w ministerstwie, w tym przez stosowanie podejścia procesowego i projektowego oraz udziału zarządzania ryzykiem w ministerstwie, udziału przedstawicieli kierowanego departamentu w samoocenie według wspólnej Metody samooceny (CAF) oraz realizację zadań związanych z funkcjonowaniem ZSZ.

W ramach funkcjonującego ZSZ, w celu jego utrzymania i doskonalenia, podejmowano w urzędzie następujące działania (Ministerstwo Gospodarki, 2015, s. 10):

- stosowanie wymagań ZSZ, w tym zawartych w dokumentacji systemowej,

- monitorowanie funkcjonowania, ZSZ,

- przeprowadzanie audytów ZSZ zgodnie z rocznym programem,

- przeprowadzanie przeglądów zarządzania,

- poddawanie ZSZ ocenie zewnętrznej jednostki certyfikującej,

- okresowe przeprowadzanie samooceny Ministerstwa Gospodarki, 
- okresowe przeprowadzanie szacowania ryzyka,

- ciągłe doskonalenie ZSZ przez realizację działań doskonalących.

\section{WYNIKI BADAŃ JAKOŚCIOWYCH}

\section{Kompetencje pracowników i kadry zarządzającej dotyczące ZSZ}

Prawie wszyscy pracownicy biorący udział w badaniu (90\%) swoje kompetencje w zakresie ZSZ ocenili pozytywnie. Ponad połowa respondentów (53\%) oceniła swoje kompetencje dostatecznie, a 37\% badanych określiło je jako wysokie i bardzo wysokie. W tym osoby zajmujące stanowiska kierownicze oceniły swoje kompetencje dostatecznie (17 osób) i wysoko (17 osób). Natomiast pozostali pracownicy oceniali: bardzo nisko - 2 respondentów, dostatecznie - 75 respondentów, wysoko 37 - respondentów, bardzo wysoko - 9 respondentów.

Udział w szkoleniach na temat ZSZ deklaruje 63\% ogółu pracowników, a prawie połowa (46\%) twierdzi, że uczestniczy we wdrażaniu systemu zarządzania. Wśród respondentów reprezentujących kadrę kierowniczą większość (71\%) brało udział w szkoleniach związanych z ZSZ, ponad połowa (60\%) twierdzi, że uczestniczyła we wdrażaniu ZSZ. W tym 4 osoby pełniły funkcję koordynatora bądź zastępcy koordynatora departamentalnego ZSZ.

Generalnie tylko $1 / 3$ pracowników ocenia, że odbyte szkolenia w zakresie ZSZ mają wpływ na zmianę postrzegania systemu, a prawie 1/5 nie ma zdania na ten temat. Wśród kadry kierowniczej 12 respondentów oceniło, że odbyte szkolenia mają pozytywny wpływ na zmianę postrzegania systemu, 8 respondentów było przeciwnego zdania, a 7 osób odpowiedziało „trudno powiedzieć”. Również wśród pozostałych pracowników (niezajmujących stanowiska kierownicze) 46 osób wskazywało, że odbyte szkolenia mają pozytywny wpływ na zmianę postrzegania systemu, a 23 osoby były przeciwnego zdania, a kolejne 23 osoby odpowiedziały „trudno powiedzieć”.

Częstotliwość udziału w szkoleniach prawie 40\% ogółu badanych osób oceniło ją jako wystarczającą, a niewiele mniej 31\% osób jako niewystarczającą. Wśród kadry kierowniczej 12 osób oceniło ją również jako wystarczającą, 7 osób wskazało, że nie jest ona wystarczająca, natomiast 11 osób odpowiedziało „trudno powiedzieć”.

Natomiast jakość i przydatność dotychczasowych szkoleń dotyczących ZSZ w urzędzie została oceniona pozytywnie przez znaczącą część uczest- 
ników badania (87\%), w tym ocenę wysoką i bardzo wysoką podało 39\% respondentów, a dostateczną prawie połowa (48\%). Również większość przedstawicieli kadry kierowniczej dostatecznie (12 osób) i wysoko (9 osób) oceniło jakość i przydatność szkoleń. Ocenę „nisko” dało 5 osób. Podobny rozkład odpowiedzi można zauważyć w odniesieniu do pozostałych pracowników, gdzie 44 osób tę jakość i przydatność oceniło dostatecznie, 35 osób wysoko i bardzo wysoko, a 10 nisko i bardzo nisko.

Na pytanie, czy w urzędzie w wystarczającym stopniu są podnoszone kwalifikacje i kształtowana jest świadomość w zakresie ZSZ ponad $1 /{ }_{4}$ ogółu respondentów (28\%) odpowiedziało „tak” i 1/4 (21\%) „nie”, a ponad połowa (51\%) nie miała zdania w tym zakresie. Również wśród osób zajmujących stanowiska kierownicze 14 osób na powyższe pytanie odpowiedziało „tak”, kolejne 16 osób „trudno powiedzieć”, 8 osób „nie”. Z podobną tendencją odpowiadali pozostali pracownicy (niepełniący stanowisk kierowniczych) - 73 osoby nie miały zdania na ten temat „trudno powiedzieć”, 35 osób wskazywało, że w wystarczającym stopniu podnoszone są kwalifikacje i kształtowana świadomość w zakresie ZSZ, a pozostałe 29 osób było przeciwnego zdania.

Biorąc pod uwagę kwestie jakości i przydatności szkoleń, oceny wyrażane przez respondentów są pozytywne. Przedstawiciele kadry kierowniczej oceniali je: dostatecznie (12 respondentów), wysoko i bardzo wysoko (10 respondentów), nisko (5 respondentów). Pozostali pracownicy oceniają tę jakość i przydatność dostatecznie (44 respondentów), wysoko i bardzo wysoko (35 respondentów), 10 osób nisko.

Podsumowując powyższe, wskazać należy, że pracownicy chociaż uczestniczyli w szkoleniach na temat ZSZ, w urzędzie nie w pełni identyfikują się z osobistym zaangażowaniem we wdrażania tego systemu w urzędzie. Zjawisko to jest zdecydowanie bardziej widoczne wśród pracowników niebędących przedstawicielami kadry kierowniczej. Ta druga grupa zdecydowanie bardziej zauważa, że uczestniczy we wdrażaniu systemu w urzędzie. Chociaż to i tak jest to niski poziom w porównaniu $\mathrm{z}$ de facto $100 \%$ pracowników urzędu zaangażowanych i uczestniczących we wdrażanie systemu ZSZ.

Z powyższego wynika, że wśród wszystkich pracowników bez względu na pełnione funkcje istnieje potrzeba zwiększenia działalności szkoleniowo-edukacyjnej na temat zarządzania jakością, w tym zintegrowanego systemu zarzą- 
dzania, a dotychczasowa działalność w tym zakresie jest oceniana bardzo pozytywnie. Chociaż wyniki badań potwierdzają, że istnieje większa konieczność ciągłego podnoszenia kwalifikacji i świadomości w zakresie ZSZ w ramach systematycznych szkoleń.

\section{KorZYŚCI Z ZSZ DLA ORGANIZACJI}

Zestawienie korzyści wynikających z wdrażania rozwiązań na rzecz jakości, w tym zintegrowanego systemu zarządzania, jakie dostrzegają pracownicy urzędu, zaprezentowano w tabeli 1 .

$\mathrm{Na}$ podstawie wyżej przedstawionych danych empirycznych można stwierdzić, że pracownicy urzędu zauważają, iż ZSZ przynosi korzyści dla organizacji. Zdaniem osób zajmujących stanowiska kierownicze w urzędzie wdrożenie ZSZ największy pozytywny wpływ miało na uporządkowanie trybu procedowania w sprawach (26 wskazań). Pozytywnie wpłynęło również na polepszenie komunikacji w MG (19 wskazań), poprawę współpracy między komórkami organizacyjnymi w urzędzie (17 wskazań), poprawę współpracy pomiędzy pracownikami (16 wskazań), promowanie nowych rozwiązań usprawniających działania urzędu (15 wskazań). Ta ostatnia odpowiedź wśród pozostałych pracowników uplasowała się na trzeciej pozycji wśród korzyści wynikających z wdrożenia ZSZ w urzędzie. Pozostałe odpowiedzi udzielane przez tę grupę pracowników ukształtowały się na zbliżonym poziomie $\mathrm{w}$ porównaniu $\mathrm{z}$ odpowiedziami udzielanymi przez osoby zajmujące stanowiska kierownicze.

Wśród innych obszarów, w których dostrzegane są korzyści z wprowadzenia ZSZ w urzędzie, przedstawiciele kadry kierowniczej wskazywali na dwa główne obszary podnoszenia wiedzy i świadomości pracowników w zakresie bezpieczeństwa informacji oraz korzyści wizerunkowe w kontaktach i relacjach zewnętrznych. Natomiast pozostali pracownicy wskazywali na kwestie zwiększania aktywności pracowników, podnoszenie kultury organizacyjnej i jakości pracy oraz podnoszenie świadomości i wiedzy pracowników w zakresie dobrych praktyk i nowoczesnych standardów zarządzania jakością i bezpieczeństwem informacji. Ponadto funkcjonowanie ZSZ w urzędzie według pracowników wspierało rozwiązywanie problemów z zakresu obszarów nakładania się kompetencji komórek organizacyjnych urzędu. 


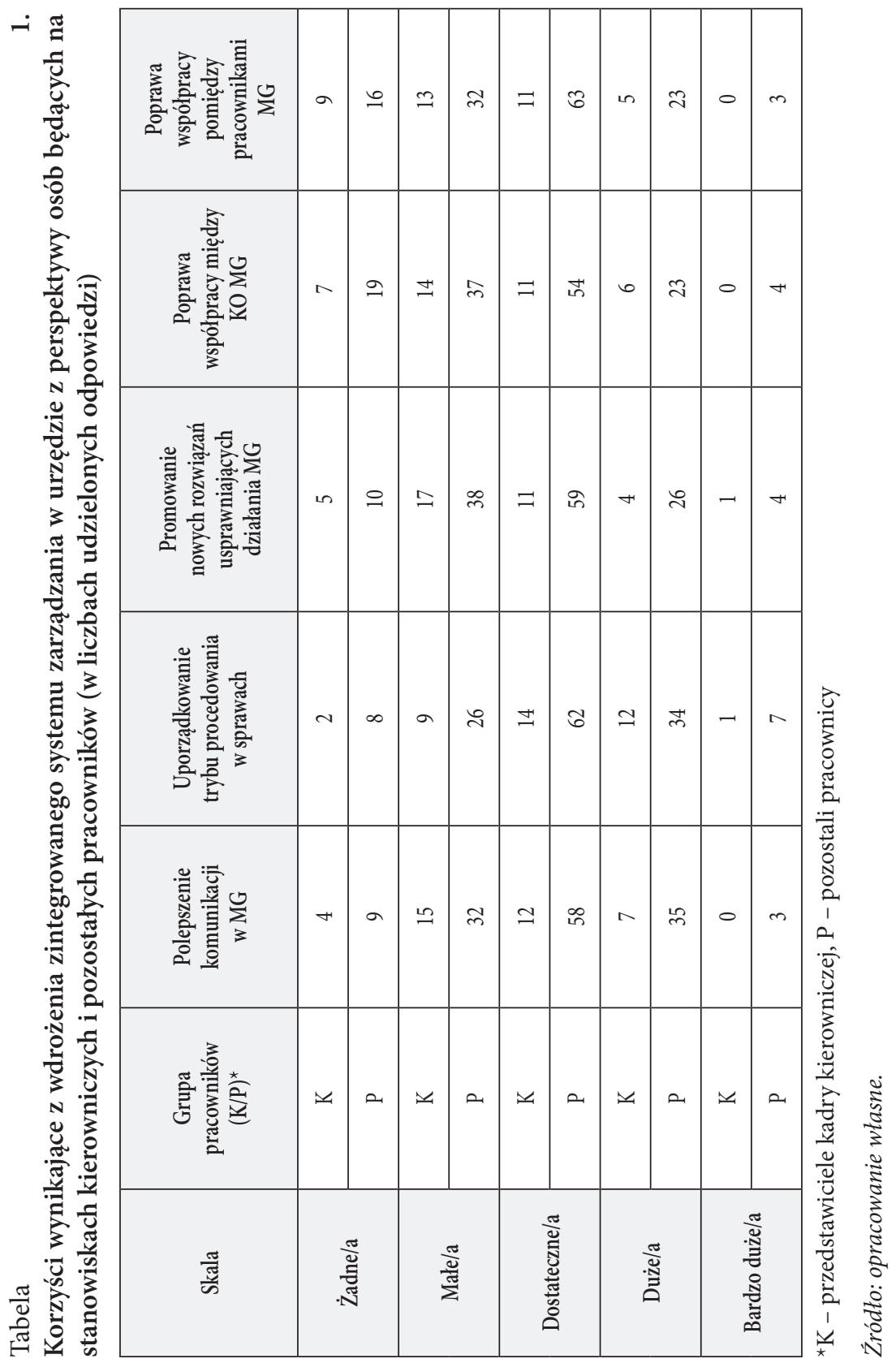




\section{OCENA FUNKCJONOWANIA ZSZ}

Na potrzeby osiągnięcia celów badawczych respondentów pytano o stopień oczekiwań wobec wdrożenia ZSZ w urzędzie i jego rolę w ciągłym doskonaleniu funkcjonowania i prowadzonej działalności przez jednostkę. W pierwszej kwestii zdecydowana połowa (66\%) uczestników badania wskazała, że wdrożony ZSZ spełnił ich oczekiwania, jednak w tym 53\% oceniło go na stopień dostateczny. Przeciwnego zdania była $1 / 3$ respondentów. Wdrożenie systemu zarządzania dla osób zajmujących stanowiska kierownicze spełniło oczekiwania w stopniu wysokim (6 wskazań), dostatecznym (16 wskazań) i niskim (14 wskazań). Dla pozostałych pracowników (77 wskazań) wdrożenie ZSZ w dostateczny sposób spełniło oczekiwania i dla 17 osób w „wysokim” i „bardzo wysokim”. Dla 37 osób spełnienie tych oczekiwań oceniono w stopniu niskim.

Również dla 1/3 ogółu uczestników badania zintegrowany system zarządzania nie pełni żadnej albo małą rolę w ciągłym doskonaleniu organizacji. W tej kwestii zdecydowanie bardziej krytycznie wypowiadali się przedstawiciele stanowisk kierowniczych aniżeli pozostali pracownicy.

Pozytywnego zdania na temat wpływu wdrażania zintegrowanego systemu zarządzania dla rozwoju i funkcjonowania instytucji jest 69\% uczestniczących w badaniu pracowników. Pracownicy niebędący na stanowiskach kierowniczych zdecydowanie częściej nie mieli zdania na ten temat.

W badaniu ocenie poddana została użyteczność ZSZ dla funkcjonowania urzędu prowadzonych działań audytowych w ramach funkcjonowania zintegrowanego systemu zarządzania. Prawie połowa ogółu badanych pracowników (42\%) wskazuje, że wyniki prowadzonych, w ramach ZSZ, audytów dostarczają informacji pomocnych dla poprawy realizacji procesów, to jednak 30\% nie ma zadania na ten temat. Częściej na tę użyteczność wskazują pracownicy będący na stanowiskach kierowniczych.

\section{UWARUNKOWANIA FUNKCJONOWANIA ZSZ W ORGANIZACJI}

Jednym $\mathrm{z}$ istotnych poddanych analizie obszarów funkcjonowania ZSZ w urzędzie są jego uwarunkowania. Analizie poddane zostały czynniki ułatwiające i utrudniające funkcjonowanie badanego systemu w organiza- 
cji. Wśród czynników ułatwiających zdecydowanie na pierwszym miejscu uplasowała się „świadomość pracowników”, 4 na 10 pracowników wskazało tę odpowiedź. Połowę mniej, bo 21\%, 19\% i 18\% respondentów wskazało „Zaangażowanie Kierownictwa” oraz odpowiednio „stawianie konkretnych wymagań przez system” i „poprawne zastosowanie podejścia procesowego”. Respondenci reprezentujący poddane badaniu obie grupy pracowników odpowiadali w tym zakresie tak samo. Osoby na stanowiskach kierowniczych jako inne czynniki, ułatwiające funkcjonowanie ZSZ w urzędzie, wymieniały zaangażowanie pracowników, stawianie celowych, w wymiarze praktycznym, wymagań przez system. A pozostali pracownicy podkreślali nastawienie na treść i efektywność dokumentacji, a nie na jej formę oraz strukturę koordynatorów departamentalnych.

$\mathrm{Z}$ drugiej strony w badaniu określono czynniki utrudniające funkcjonowanie ZSZ w urzędzie. Prawie $1 / 3$ respondentów wskazała na aspekt nadmiernie rozbudowanej dokumentacji. Jako czynnik utrudniający funkcjonowanie ZSZ - „brak postrzegania systemu jako wzajemnie powiązanych i oddziałujących elementów”, „niewystarczające przygotowanie pracowników do pracy w systemie i niedostosowanie wymagań systemu do specyfiki urzędu” wskazywało 15-16\% badanych pracowników. Tylko 1 na 10 uczestniczących w badaniu zauważał problem w niewystarczającym zaangażowaniu kierownictwa urzędu. Również dla obydwu badanych grup pracowników rozkład odpowiedzi był zbliżony. Natomiast wśród innych czynników utrudniających funkcjonowanie ZSZ w urzędzie, osoby będące na stanowiskach kierowniczych wskazywały na rozbudowany system opiniowania/zatwierdzania procesów i procedur, dużą liczbę procesów i procedur i nieznajomość procesów i procedur. Natomiast pozostali pracownicy wskazywali na dublowanie się zapisów w procesach z zapisami zawartymi w aktach prawa wewnętrznego, funkcjonowanie ZSZ oparte jest w głównej mierze na pracy koordynatorów departamentalnych i audytorów ZSZ, brak przekonania pracowników do ZSZ, duplikację procedur ogólnie funkcjonujących w ramach systemu - brak spójności i przejrzystości i brak wystarczających zasobów.

W celu rzetelnej oceny uwarunkowań funkcjonowania zintegrowanego systemu zarządzania w urzędzie zapytano pracowników o ich problemy dotyczące funkcjonowania ZSZ, z jakimi mają do czynienia z perspektywy 
własnego stanowiska pracy. Rozkład odpowiedzi jest dość różnorodny. Nie uzyskano jednej zdecydowanej odpowiedzi. Co 3 respondent jako problem wskazywał konieczność opracowania dokumentacji, co 2 respondent zauważał niewystarczające zaangażowanie pracowników i audyty wewnętrzne. Jeden na 10 badanych wskazywał niewystarczające zaangażowanie kierownictwa. Generalnie respondenci obu badanych grup pracowników odpowiadali podobnie (tabela 2 ).

Tabela 2.

$\mathrm{Z}$ jakimi problemami dotyczącymi funkcjonowania ZSZ w urzędzie spotyka się Pani/Pan? (wg udzielanych odpowiedzi)

\begin{tabular}{|c|c|}
\hline \multicolumn{2}{|c|}{$\begin{array}{c}\text { Problemy dotyczące funkcjonowania ZSZ, z jakim mają pracownicy } \\
\text { do czynienia z perspektywy własnego stanowiska pracy }\end{array}$} \\
\hline Osoby pełniące stanowiska kierownicze & Pozostali pracownicy \\
\hline Opracowanie dokumentacji & Opracowanie dokumentacji \\
\hline Audyty wewnętrzne & Aiewystarczające zaangażowanie pracowników \\
\hline $\begin{array}{c}\text { Niewystarczające zaangażowanie } \\
\text { pracowników }\end{array}$ & Monitronewe \\
\hline Monitorowanie procesów & Niewystarczające zaangażowanie kierownictwa \\
\hline $\begin{array}{c}\text { Niewystarczające zaangażowanie } \\
\text { kierownictwa }\end{array}$ & \\
\hline
\end{tabular}

Źródto: opracowanie własne.

Wśród innych problemów, dotyczących funkcjonowania ZSZ, wskazano m.in.: zbyt dużą liczbę procesów i procedur, niezrozumienie celu funkcjonowania systemu czy zbyt duże obciążenia pracowników merytorycznych.

Jednym z ostatnich celów podjętych badań było zbadanie, czy zwiększenie obciążenia pracowników obowiązkami wynikającym ze ZSZ jest adekwatne do korzyści, jakie pracownicy widzą w tym systemie w urzędzie. Czterdzieści cztery procent ogółu respondentów wykazała, że obciążenie ich obowiązkami nie jest adekwatne do osiąganych korzyści. Zdaniem połowy osób będących na stanowiskach kierowniczych (19 wskazań) i mniej 
niż 43\% pozostałych pracowników twierdzi, że zwiększenie obciążenia pracowników obowiązkami wynikającymi z ZSZ nie jest adekwatne do korzyści z wprowadzania tego systemu.

Ostatnim analizowanym zagadnieniem były propozycje badanych pracowników dotyczące zmian w ZSZ, a w szczególności ewentualne kierunki jego usprawnienia. Propozycje zmian dotyczyły wielu aspektów działalności urzędu, co zaprezentowano w poniższej tabeli 3.

Tabela 3.

Propozycje zmian w odniesieniu do funkcjonującego ZSZ w opinii pracowników

\begin{tabular}{|c|c|}
\hline \multicolumn{2}{|c|}{ Propozycje zmian w odniesieniu do funkcjonującego zintegrowanego systemu zarządzania } \\
\hline Osoby pełniące stanowiska kierownicze & Pozostali pracownicy \\
\hline Ograniczenie dokumentacji & Dalsze upraszczanie dokumentacji \\
\hline Zmniejszenie liczby procesów i procedur & Zmniejszanie liczby procesów \\
\hline $\begin{array}{c}\text { Uproszczenie systemu opiniowania i zatwier- } \\
\text { dzania procesów i procedur }\end{array}$ & Ograniczenie liczby audytów \\
\hline $\begin{array}{c}\text { Zmniejszenie obciążeń związanych z obsługą } \\
\text { ZSZ }\end{array}$ & Zmianę systemu opiniowania kart procesu \\
\hline $\begin{array}{c}\text { Wprowadzenie dodatków za pracę związaną } \\
\text { z ZSZ }\end{array}$ & Weryfikacja właścicieli procesów oraz struktury \\
organizacyjnej
\end{tabular}

Źródło: opracowanie własne.

\section{Posumowanie}

Na podstawie powyższych wyników badań i przeprowadzonej analizy wyciągnięte zostały wnioski weryfikujące postawione hipotezy badawcze. Hipoteza $\mathrm{H} 1$ została potwierdzona nie w pełni. Zaobserwowane braki w samoocenie kompetencji pracowników urzędu, jakie wykazane zostały w badaniu, nie pozwalają na potwierdzenie tezy. Badania wykazały, że zjawiskiem 
charakterystycznym dla badanego urzędu są dość wysokie kompetencje i zaangażowanie pracowników urzędu we wdrażanie ZSZ. Ale istnieje konieczność dalszego budowania świadomości na temat narzędzi i roli ZSZ wśród pracowników urzędu m.in.: promocję postaw projakościowych i budowanie wiedzy na temat funkcjonowania i doskonalenia systemów zarządzania jakością w administracji publicznej. Z powyższego wynika, że wśród wszystkich pracowników bez względu na pełnione funkcje istnieje potrzeba zwiększenia działalności szkoleniowo-edukacyjnej na temat zarządzania jakością, w tym ZSZ, a dotychczasowa działalność w tym zakresie jest oceniana bardzo pozytywnie. Hipoteza $\mathrm{H} 2$ została potwierdzona. Urząd dysponuje potencjałem w postaci własnych pracowników, którzy w następstwie potrafią identyfikować korzyści oraz czynniki ułatwiające i utrudniające wdrażanie we własnym urzędzie polityki zarządzania jakością, w tym ZSZ. Badania wykazały, że zarówno w świadomości osób na stanowiskach kierowniczych i pozostałych pracowników wdrożony ZSZ sprzyja doskonaleniu i poprawie funkcjonowania urzędu. Hipoteza H3 została potwierdzona. Badania wykazały duże zaangażowanie kierownictwa w problematykę zarządzania jakością. Nie są obserwowane negatywne postawy kierownictwa i deklarowane jest wystarczające zaangażowanie i wsparcie w faktycznym i istotnym zakresie w doskonaleniu systemów zarządzania w urzędzie. Zaangażowanie kierownictwa jest postrzegane jako kluczowe ułatwienie dla podejmowanych działań w urzędzie w badanym zakresie.

Na podstawie zrealizowanych badań oraz wniosków, jakie powstały w ich następstwie, należy rozważyć rekomendacje działań, prowadzących do doskonalenia zintegrowanego systemu zarządzania w urzędzie. Źródło sukcesów, a jednocześnie zagrożenie porażek w zakresie wdrażania i doskonalenia zintegrowanego systemu zarządzania związane jest ze stanem kapitału intelektualnego i organizacyjnego. Uzupełniające się wzajemnie wiedza, doświadczenie, zaangażowanie, motywacja czy umiejętności kierownicze i zaangażowanie kierownictwa stanowią podstawowe warunki skutecznych wdrożeń. Świadome oczekiwania względem systemu, umiejętne definiowanie korzyści kosztów i korzyści, rozwijanie świadomości kierownictwa oraz pracowników urzędu stanowią warunek niezbędny, prowadzący do doskonalenia systemu zarządzania i zwiększania jego efektywności. Oczywiście 
systemy zarządzania są systemami dobrowolnego stosowania (Sagan, 2017, s. 75-81). Również z punktu widzenia jakości nie jest istotna droga, jaka zostanie obrana przez organizacje.

Podsumowując propozycje zmian wynikające $\mathrm{z}$ badań $\mathrm{w}$ odniesieniu do funkcjonującego w urzędzie ZSZ, można zawrzeć w trzech zasadniczych obszarach (rysunek 1).

Rysunek 1.

Proponowane obszary usprawnienia funkcjonującego ZSZ w urzędzie.

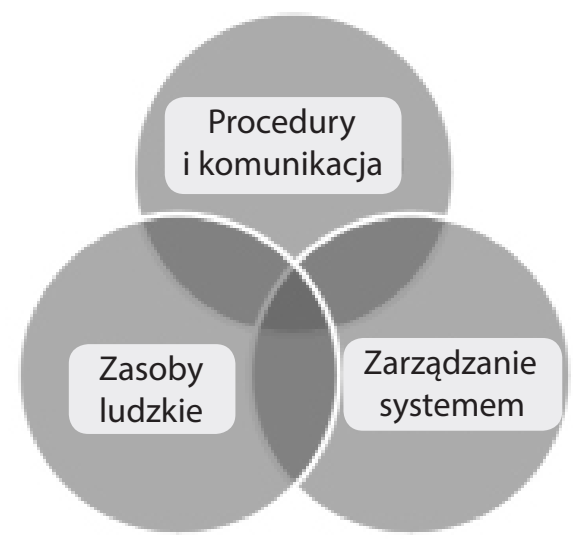

Źródto: opracowanie wtasne.

Zmiany w obszarze „Procedury i dokumentacja” okazały się najistotniejszym utrudnieniem i obszarem wymagającym modyfikacji. Za kwestie wymagające usprawnienia funkcjonowania ZSZ należy uznać: ilość dokumentacji, liczbę procesów i procedur oraz wymagania związane z opiniowaniem procesów i procedur i szacowaniem ryzyk, system opiniowania oraz zatwierdzania procesów i procedur czy liczbę prowadzonych audytów. Generalnie warto rozważyć uproszczenie systemu i/lub docelowo zastosowanie dedykowanej jemu aplikacji.

Propozycje zmian odnoszące się do zarządzania systemem i informacją dotyczą głównie możliwości zwiększenia dostępności informacji o systemie i wykorzystania informacji, jakie daje system do analizy sytuacji w urzędzie przez możliwości zaradzenia zidentyfikowanym w ten sposób problemom. Waż- 
nym zagadnienie dla funkcjonowania ZSZ w urzędzie i jego efektywności konieczna jest potrzeba zintegrowania systemu z kontrolą zarządczą i budżetem zadaniowym oraz dalszego doskonalenia systemu jako narzędzia kontroli zarządczej w urzędzie.

Kolejnym istotnym obszarem wymagającym usprawnień jest obszar „Zasoby ludzkie" (nazwany tak na potrzeby artykułu). Zasadnicze rekomendacje dotyczą podnoszenia świadomości na temat projakościowych działań w urzędzie, w tym ZSZ, wśród pracowników wszystkich szczebli. Ale oprócz budowania świadomości na temat zarządzania jakością, ważne jest podnoszenie poziomu wiedzy i wdrożenie dedykowanych szkoleń, również w formule e-learningu i warsztatów. Istotną dla efektywności podejmowanych działań jest również kwestia obciążenia pracowników i zaangażowania odpowiedniej ilości osób w realizację ZSZ, w tym konieczność oszacowania i wyceny niezbędnej pracochłonności działań w zakresie utrzymania ZSZ i oddelegowanie niezbędnych zasobów.

Kluczowe jest wspólne rozumienie problemów jakości, wspólne jej definiowanie i stworzenie środowiska jej przyjaznego - przez projakościową kulturę organizacyjną, pozwalającą na budowanie projakościowej orientacji pracy. W świetle tak sformułowanych rekomendacji i wniosków urzędy administracji publicznej mają dzisiaj wszelkie możliwości do tego, aby wykonać kolejny krok na drodze do doskonalenia jakości funkcjonowania i świadczonych usług. Wdrożenie systemów na rzecz jakości powinny przyczynić się do poprawy zdolności organizacyjnych i zarządczych.

\section{Literatura}

Buchacz, T., WysockiS.(2016).Zarządzaniejakością wadministracji-europejskiewzorce, polskie doświadczenia, [w:] Czaputowicz J. (red.) Administracja Publiczna. Wyzwania $w$ dobie integracji europejskiej, Warszawa: PWN. ISBN 9788301166410.

Bugdol, M. (2008). Zarzadzanie jakościa w urzędach administracji publicznej, Warszawa: Wydawnictwo Difin. ISBN 9788372519016.

Bugdol, M., Krawczyk T. (2003). Ocena systemu zarządzania jakością w administracji publicznej, „Problemy Jakości” 10. ISSN 0137-8651.

Frąś, J. (red.) (2008). Zarządzanie jakością usług w instytucjach publicznych, Szczecin: Uniwersytet Szczeciński. ISBN 9788372416971. 
Gross-Gołacka, E. (2016). Rola koncepcji zarządzanie różnorodnością w doskonaleniu organizacji, „Problemy Jakości” 4, s. 28-34. ISSN 0137-8651.

Gross-Gołacka, E., (2014). Zarzadzanie wiedza w organizacjach administracji rzadowej. Dobre praktyki doskonalenia zarządzania-zarządzanie wiedza, Warszawa: Ministerstwo Gospodarki.

Kleniewski, A. (2007). Integracja systemów zarządzania - specyfikacja PAS 99:2006, „Problemy Jakości” 10, s. 12-17. ISSN 0137-8651.

Koryś, P., Trutkowski, C. (2001). Badanie Systemu Przeciwdziałania Zagrożeniom Korupcyjnym w Ministerstwie Gospodarki. Raport końcowy, Warszawa: Fundacji im. Stefana Batorego.

Kozera, Z. (2009). Diagnoza modelu zarządzania jakością w administracji rządowej. Kapitał intelektualny jako determinanta realizacji polityki jakości w urzędach administracji rządowej, Warszawa: Kancelaria Prezesa Rady Ministrów.

Ksiega Zintegrowanego Systemu Zarządzania, Wersja 9, Wydanie 1 z dnia 14 września 2015 r. (2015), Warszawa: Ministerstwo Gospodarki.

Modzelewski, P., Opolski, K. (2004). Zarządzanie jakością w usługach publicznych, Warszawa: CeDeWu. ISBN 9788375560107.

Opolski, K., Dykowska, G., Możdżonek, M. (2009). Zarzadzanie przez jakość w usługach zdrowotnych. Teoria i praktyka, Warszawa: CeDeWu. ISBN 8387885320.

Opolski, K., Modzelewski, P. (2004). Zarządzanie jakościq w administracji samorzqdowej - wnioski $z$ doświadczeń międzynarodowych, „Samorząd Terytorialny” 10. ISSN 0867-4973.

PAS 99: (2006) Publicly Available Specification. Specification of common management system requirements as a framework for integration, $\mathrm{s}$. V.

Roszak, M. (2012). Integracja systemów zarzadzania - koncepcje i praktyka. W Zintegrowany system zarządzania w usługach, Lublin: Katedra Zarządzania Jakością i Wiedzą UMCS w Lublinie.

Sagan, S. (2017). Zintegrowany system zarządzania a zwinne przedsiębiorstwo, [w:] E. Skrzypek, Zarządzanie jakościq w nowoczesnej organizacji - uwarunkowania i konsekwencje (s. 75-81), Lublin: Katedra Zarządzania Jakością i Wiedzą, UMCS, Lublin.

Sejm Rzeczpospolitej Polskiej, Odpowiedź ministra gospodarki na interpelację nr 15542 w sprawie zasadności wprowadzenia zintegrowanego systemu zarządzania ISO oraz systemu przeciwdziałania zagrożeniom korupcyjnym w Ministerstwie Gospodarki (pismo z dnia 20 marca 2013 r., znak: SPS-023-15542/13), 
http://www.sejm.gov.pl/Sejm7.nsf/InterpelacjaTresc.xsp?key=167CB5D9 [dostęp: 22.04.2015].

Sitek, M. (2009). Wpływ wybranych czynników na rozwój małych i średnich przedsiębiorstw w Polsce, [w]: M. Okręglicka, O. Ławińska (red.). Determinanty rozwoju małych i średnich przedsiębiorstw w Polsce, Częstochowa: Wydawnictwo Politechniki Częstochowskiej. ISBN 9788371934537.

Sitek, M. (2012)Prawne i instytucjonalne ramy polityki karnej UE, Journal of Modern Science" 1(12), s. 185-202. ISSN 1734-2031.

Skrzypek, E. (2014). Integracja zarządzania $w$ warunkach nowej gospodarki jako szansa na sukces rynkowy, [w:] Integracja zarzadzania w warunkach GOW, Lublin: Katedra Zarządzania Jakością i Wiedzą UMCS w Lublinie.

Szejniuk, A. (2014). Warunki pracy a efektywność przedsiębiorstwa, „Journal of Modern Science" 1/20, s. 245-262. ISSN 1734-2031.

Szejniuk, A. (2015). Kapitał Ludzki jako wyznacznik sukcesu organizacji, „Journal of Modern Science" 3/26, s. 47-60. ISSN 1734-2031.

Tkaczyk, St., Kowalska-Napora, E. (2012). Strategia zarzadzania jakością, Warszawa: Difin. ISBN 9788376416694.

Ustawa z dnia 14 czerwca 1960 r. - Kodeks postępowania administracyjnego, Dz.U. z 2017 r. poz. 1257.

Walsh, K. (1991). Quality and public services, „Public Administration”, vol. 69, p. 503-514.

Zarządzenie Ministra Gospodarki w prawie podziału pracy w Kierownictwie.

Zarządzenie Ministra Gospodarki z dnia 15 kwietnia 2014 r. w sprawie ustalenia regulaminu organizacyjnego w Ministerstwie Gospodarki.

Zarządzenie nr 48 Dyrektora Generalnego z dnia 18 czerwca 2014 r. w sprawie Zintegrowanego Systemu Zarządzania. 